congeals, they were encouraged to feel proud of their powers and free to express them. This is one reason why the Court Theatre of London, where we played Major Barbara, has the reputation of 'discovering' so many good actors. Many who have played for years elsewhere without particular success have achieved great distinction there.

\title{
NOTES
}

1. Rosina Filippi (1866-1930) played Lady Britomart.

2. Louis Calvert (1859-1923) played Andrew Undershaft. The previous year he had created Broadbent in John Bull's Other Island.

\section{Major Barbara: III}

\section{ALFRED SUTRO}

From Alfred Sutro, Celebrities and Simple Souls (London: Duckworth, 1933) pp. 117-18. Alfred Sutro (1863-1933), playwright and translator of Maeterlinck, remembers the first performance of Major Barbara.

I was at the first performance of that play; all the intelligentsia of London were there, and the first two acts were received with rapturous enthusiasm. Going into the lobby, after the curtain had fallen on Act II, I met Shaw, and warmly congratulated him on what I declared was a masterpiece, and the best play he had written, 'If the last act is as good as the other two,' I said - Shaw stopped me. 'The last act plays for an hour,' he chuckled, 'and it's all talk, nothing but talk!' My face fell; I was sorry. 'Don't you worry,' said Shaw, as he patted me on the shoulder, 'you'll see - they'll eat it!'

Well, they didn't. The curtain rose on an audience that had been hugely entertained, that was happily and confidently expectant; but, alas, there were streams, rivers, cataracts of talk, talk that caught us up, engulfed us and drowned us; the intense boredom in front seemed to infect the actors on the stage, and a little fluffiness on the part of the principal, the unending, talker, did not help matters. Never was the end of a play received with more rapturous relief, but, as the audience filed out, the brilliance of the first two acts was held to atone, in some measure, for the spate of talk that had flooded the last one. 